\title{
Will the SARB always succeed in fighting inflation with contractionary policy?
}

GUANGLING (DAVE) LIU

\section{Stellenbosch Economic Working Papers: 15/11}

\author{
KEYWORDS: MONETARY POLICY, PRICE PUZZLE, INFLATION TARGETING, NEW \\ KEYNESIAN MODEL
}

JEL: E52, E31, E58, E12

GUANGLING (DAVE) LIU

DEPARTMENT OF ECONOMICS

UNIVERSITY OF STELLENBOSCH

PRIVATE BAG X1, 7602

MATIELAND, SOUTH AFRICA

E-MAIL: GLIU@SUN.AC.ZA

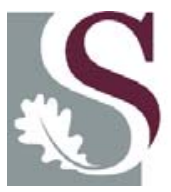

UNIVERSITEIT

STELLENBOSCH

UNIVERSITY

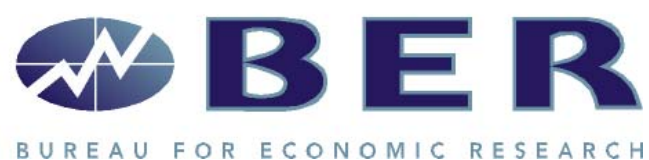

BUREAU FOR ECONOMIC RESEARCH

A WORKING PAPER OF THE DEPARTMENT OF ECONOMICS AND THE BUREAU FOR ECONOMIC RESEARCH AT THE UNIVERSITY OF STELLENBOSCH 


\title{
Will the SARB always succeed in fighting inflation with contractionary policy?
}

\author{
GUANGLING (DAVE) LIU
}

\section{ABSTRACT}

The conventional view is that a monetary policy shock has both supply-side and demand-side effects, at least in the short run. Barth and Ramey (2001) show that the supply-side effect of a monetary policy shock may be greater than the demand-side effect. We argue that it is crucial for monetary authorities to understand whether an increase in expected future inflation is due to supply shocks or demand shocks before applying contractionary policy to forestall inflation. Using a standard New Keynesian dynamic stochastic general equilibrium model with the cost-channel of monetary transmission, we show that whether the South African Reserve Bank should apply contractionary policy to fight inflation depends critically on the nature of the disturbance. If an increase in expected future inflation is mainly due to supply shocks, the South African Reserve Bank should not apply contractionary policy to fight inflation, as this would lead to a persistent increase in inflation and a greater loss in output.

Keywords: Monetary policy, price puzzle, inflation targeting, New Keynesian model

JEL codes: E52, E31, E58, E12 


\section{Introduction}

The conventional view suggests that monetary authorities should adjust the nominal short-term interest rate gradually and sufficiently to alter the real rate in the direction that offsets any movement in expected future inflation (Clarida et al., 1999). A contractionary monetary policy shock should, in principle, decrease future inflation. However, empirical evidence shows a positive and significant response of price level to positive innovations in the nominal short-term interest rate, the so-called price puzzle in the literature.

Price puzzle evidence was first noted by Sims (1992) and labeled by Eichenbaum (1992). To characterize the dynamic effects of monetary policy disturbances, Sims (1992) uses vector autoregressive (VAR) models and shows that the price puzzle emerges in most developed countries, such as France, Germany, Japan, the U.K. and the U.S. That is, a contractionary monetary policy shock leads to a sharp, persistent increase in price level. As pointed out by Eichenbaum (1992), this VAR-based empirical evidence is an obvious challenge to Keynesians, Monetarists, and Real Business Cycle Theorists. According to Sims (1992), the price puzzle arises due to the misidentification of monetary policy shocks. Monetary authorities may have more information on expected future inflation than a VAR could capture. For instance, once a commodity price index is included in the VAR, econometricians would no longer observe the puzzle.

An alternative explanation for the price puzzle suggests that it is due to the cost-channel effect of monetary policy shocks. Barth and Ramey (2001) present aggregate and industry-level evidence that suggests a costchannel of monetary transmission can potentially explain the price puzzle. Studies using general equilibrium models to explicitly analyze the cost-channel (supply-side) effect of a monetary policy shock all assume firms have to borrow funds to pay their factors of production before they sell their product ${ }^{1}$. As a result, an increase in the nominal short-term interest rate increases the prices of the factors of production, and hence inflation ensues.

Besides the sharp, persistent increase in price level, a contractionary monetary policy shock also leads to a significant, persistent decline in real output. This degree of amplification puzzle noted by Bernanke and Gertler (1995) implies that contractionary policy can neither forestall inflation, nor improve the short-run output/inflation trade-off if the cost-channel of monetary transmission is present.

This paper examines the effects of monetary policy for the South African economy from a New Keynesian perspective. In particular, we study under what circumstance the South African Reserve Bank (SARB

\footnotetext{
${ }^{1}$ See Christiano and Eichenbaum (1992), Christiano et al. (1997), Farmer (1984), and Farmer (1988).
} 
hereafter) should apply contractionary policy to fight inflation ${ }^{2}$. To do so, we compare the dynamic responses of output and inflation to a contractionary policy shock in a simplified version of Smets and Wouters (2007) New Keynesian model, with and without the cost-channel of monetary cost-channel of monetary transmission. We argue that whether SARB should raise the nominal short-term interest rate in an effort to forestall inflation depends on whether an increase in expected demand shocks or supply shocks. We show that in the presence of the cost-channel of monetary transmission, the nominal short-term interest rate acts as a costpush shock: an increase in the nominal short-term interest rate raises the real marginal cost of production, and hence inflation ensues. The SARB can only succeed in fighting inflation by increasing the nominal short-term interest rate if an increase in expected future inflation is mainly due to demand shocks, or put differently, the demand-side effect dominates the cost-channel effect of monetary policy shocks.

The paper proceeds as follows. Section 2 presents the VAR-based empirical evidence for the South African economy. Section 3 describes the New Keynesian dynamic stochastic general equilibrium (DSGE) model with the cost-channel of monetary transmission. Section 4 presents the simulation results, and Section $[5$ concludes.

\section{Empirical evidence}

The VAR includes three variables, and the ordering of the variables is real output, inflation, and the nominal short-term interest rate. The estimated VAR contains four lags of each variable, and the sample period is 1970:Q1-2010:Q4. Data are taken from the SARB Quarterly Bulletin. Figure 1 presents the impulse response functions of output, inflation, and the nominal interest rate to a contractionary policy shock. A monetary policy shock is identified as a shock to the policy rate, the nominal short-term interest rate. It is not surprising that the price puzzle emerges in the South African data. In response to an increase in interest rate, inflation increases immediately and then starts declining slowly.

One explanation for the price puzzle is that it is due to the cost-channel (supply-side) effect dominating the demand-side effect of the monetary policy shock. That is, a monetary policy shock has an effect primarily through increases in production costs, resulting in an increase in aggregate prices. For instance, if an increase in expected future inflation is predicted to be due to an increase in the oil price, increasing the policy rate is not going to bring down future inflation. The increase in oil price will have already raised the production

\footnotetext{
${ }^{2}$ The SARB is one of those central banks that adopt inflation targeting as its monetary policy. Therefore, it is important for SARB to have a better understanding of the effects of monetary policy on inflation in particular.
} 
Figure 1: VAR-based empirical evidence

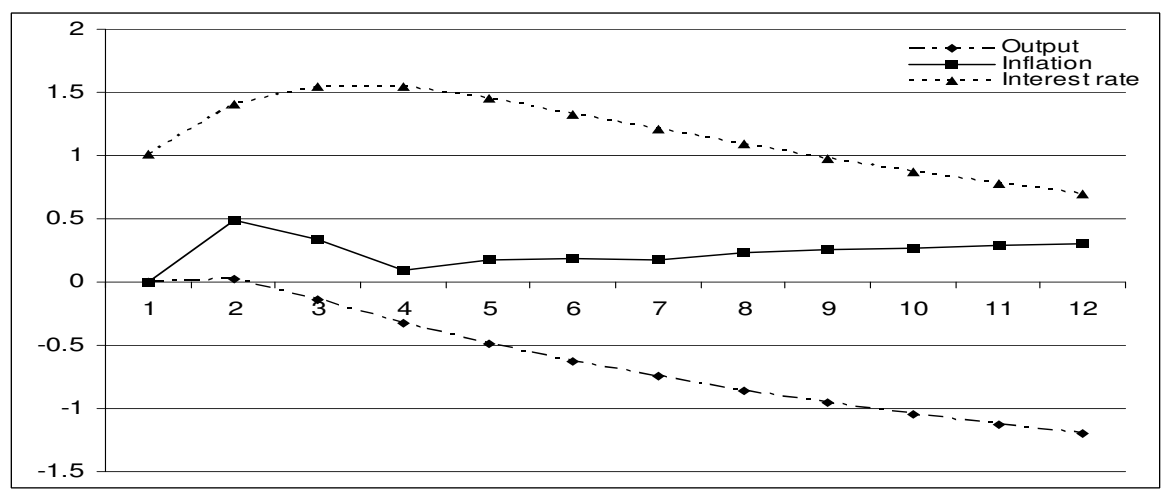

Figure 2: Inflation, interest rate, and oil price

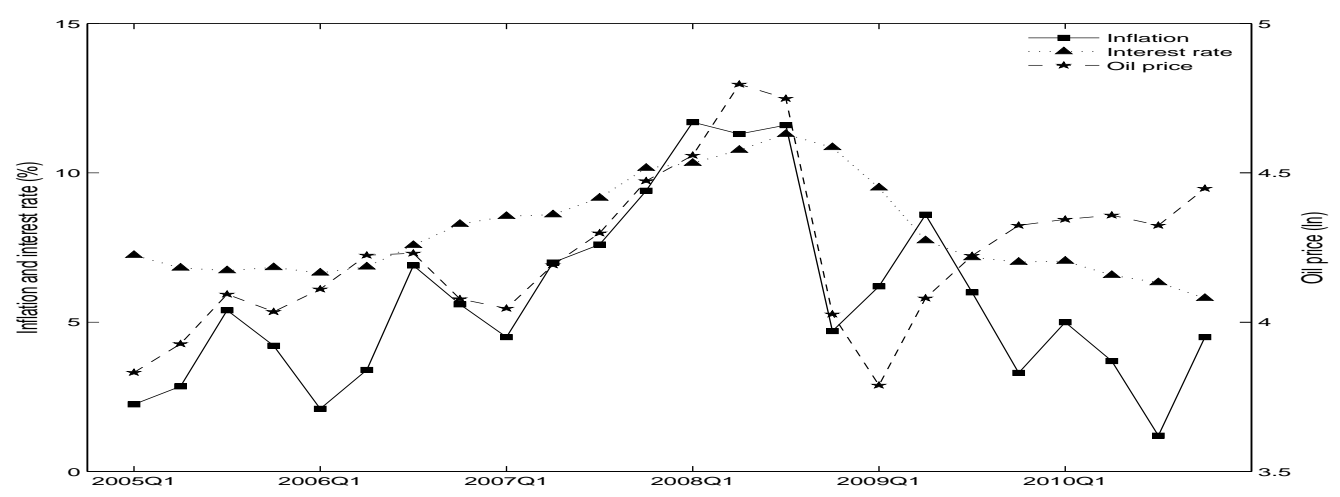


costs for firms. If the monetary authorities ignore the cost-channel effect of monetary policy shocks and simply increase the policy rate to fight inflation, it is no different to "throwing gasoline on fire" (Barth and Ramey, 2001). Figure 2 plots inflation, the nominal short-term interest rate, and the (ln) oil price during the period of 2005Q1-2010Q4. It shows that monetary policy shifts are highly correlated with oil price shocks, as suggested by Hoover and Perez (1994). The patterns for inflation and the oil price over the period 2005Q1-2009Q2 are almost identical. The oil price increased gradually from 2007Q1 to 2008Q2 and dropped sharply from 2008Q3, and inflation followed in the same manner. During the period 2007Q1-2008Q2, SARB kept hiking the interest rate without any success in fighting inflation. One might argue that it was due to the policy time lags that inflation only started declining from 2008Q3. In fact, the oil price dropped sharply from 2008Q3, indicating that during the period 2007Q1-2008Q2, the persistent increase in inflation was probably due to the cost-channel effect of monetary policy shocks.

\section{A model with the cost-channel of monetary transmission}

The basic framework of the baseline model presented here is a simplified version of Smets and Wouters (2007) model. The model has many features typical of a standard dynamic New Keynesian model with nominal rigidities. The cost-channel of monetary transmission is introduced into the model, as in Rabanal (2007). That is, a fraction of firms have to borrow funds to pay for their wage bill before selling their products.

\subsection{Households}

The economy consists of a continuum of infinitely-lived households. In each period $t=0,1,2, \ldots$, a representative household makes a sequence of decisions to maximize her expected utility over a composite consumption good $C_{t}$ and leisure $1-N_{t}$ :

$$
E \sum_{t=0}^{\infty} \beta^{t}\left[\frac{\left(C_{t}-h C_{t-1}\right)^{1-\eta_{c}}}{1-\eta_{c}}-\frac{\left(N_{t}\right)^{1+\eta_{n}}}{1+\eta_{n}}\right]
$$

where $\beta$ is the subjective discount factor. $\eta_{c}$ is the coefficient of the relative risk aversion of household and $\eta_{n}$ is the inverse of the elasticity of work effort with respect to real wage. The habit formation parameter $h$ measures the importance of the reference level relative to current consumption. As suggested by Fuhrer (2000), Amato and Thomas (2004), and Bouakez et al. (2005), including habit formation in household's utility 
function improves the short-run dynamic of the model in terms of replicating the hump-shaped response of consumption to monetary policy and other shocks.

In each time period $t$, the representative household carries the government bond $B_{t-1}$ from the previous period into the current period, and receives a lump-sum transfer $T_{t}$ from the monetary authority and a nominal profit or dividend payment $D_{t}$ from the intermediate-good firms. In addition, the household receives its usual labor income $W_{t} N_{t}$, where $W_{t}$ denotes the nominal wage. Therefore, in each time period, the representative household maximizes her expected utility (1) subject to the following budget constraint:

$$
C_{t}+X_{t}+\frac{B_{t}}{P_{t}} \leq \frac{W_{t}}{P_{t}} N_{t}+\frac{B_{t-1}\left(1+i_{t-1}\right)}{P_{t}}+\frac{D_{t}}{P_{t}}+\frac{T_{t}}{P_{t}}
$$

Besides the intertemporal budget constraint (2), the representative household is also subject to the following capital accumulation constraint as in Christiano et al. (2005):

$$
K_{t}=(1-\delta) K_{t-1}+\left[1-S\left(\frac{X_{t}}{X_{t-1}}\right)\right] X_{t}
$$

where $\delta$ is the depreciation rate, and $X_{t}$ is gross investment. The function $S$ captures the presence of investment adjustment $\cos ^{3}{ }^{3}$.

The linearized first-order conditions ${ }^{4}$ are:

$$
\begin{aligned}
c_{t} & =\frac{h}{1+h} c_{t-1}+\frac{1}{1+h} E_{t} c_{t+1}-\frac{1-h}{(1+h) \eta_{c}} r_{t} \\
p_{k, t} & =E_{t} \pi_{t+1}-r_{t}+[1-\beta(1-\delta)] E_{t} r_{k, t+1}+\beta(1-\delta) E_{t} p_{k, t+1} \\
x_{t} & =\frac{1}{1+\beta}\left(x_{t-1}+\beta E_{t} x_{t+1}+\frac{1}{\nu} p_{k, t}\right)
\end{aligned}
$$

Equation (4) is the consumption Euler equation with external habit formation. It represents the intertemporal allocation of consumption, where consumption for the current period depends on a weighted average of previous and expected future consumption. Equation (5) is the Lucas asset price equation for capital. $P_{k, t}$ is the shadow value of the installed capital, which depends on both the expected future value of capital and its return $r_{k, t}$, taking into account the depreciation rate. The investment equation (6), which

\footnotetext{
${ }^{3}$ In steady state, $S(\cdot)=0, S^{\prime}(\cdot)=0, S^{\prime \prime}(\cdot)>0$.

${ }^{4}$ A lowercase letter represents its $\log$ deviation from steady state.
} 
contains both backward-looking and forward-looking components, describes the dynamics of investment. $\nu$ is the investment adjustment cost parameter, $\nu=S^{\prime \prime}(\cdot)$.

\subsection{Final goods production}

In the final-good sector, firms are perfectly competitive. The representative firm produces the final good $Y_{t}$ using a continuum of intermediate goods $Y_{j, t}$ indexed by $j(j \in[0,1])$, according to a constant elasticity of substitution (CES) production function, as suggested by Dixit and Stiglitz (1977):

$$
Y_{t}=\left(\int_{0}^{1} Y_{j, t}^{\frac{\varphi_{p, t}-1}{\varphi_{p, t}}} d j\right)^{\frac{\varphi_{p, t}}{\varphi_{p, t}-1}}
$$

where $\varphi_{p, t}$ measures the time-varying price elasticity of demand for each intermediate good $Y_{j, t}$. It acts as a price markup shock in the goods market.

The representative firm maximizes its profit, and the first-order condition implies the demand for each intermediate good as the following:

$$
Y_{j, t}=\left(\frac{P_{j, t}}{P_{t}}\right)^{-\varphi_{p, t}} Y_{t}
$$

where $P_{j, t}$ is the price of the intermediate good $j$, and $P_{t}$ is the price for the final good. Since the final-good firms operate in a perfectly competitive market, in equilibrium the representative firm's profit should equal zero. Hence, the equilibrium market price for the final good is given as the following:

$$
P_{t}=\left(\int_{0}^{1} P_{j, t}^{1-\varphi_{p, t}} d j\right)^{1 / 1-\varphi_{p, t}}
$$

\subsection{Intermediate goods production}

In the intermediate-good sector, firms are monopolistically competitive. In each time period, the representative firm produces $Y_{j, t}$ units of intermediate good $j$ according to the following constant-returns-to-scale production function:

$$
Y_{j, t}=\xi_{z, t} K_{j, t-1}^{\alpha} N_{j, t}^{1-\alpha}, \quad 0<\alpha<1
$$


where $\xi_{z, t}$ is the technology shock.

Households supply $N_{j, t}$ units of labor to the representative firm $j$. The aggregate labor demand $N_{t}$ is given by the following Dixit-Stiglitz form:

$$
N_{t}=\left(\int_{0}^{1} N_{j, t}^{\frac{\varphi_{w, t}-1}{\varphi_{w, t}}} d j\right)^{\frac{\varphi_{w, t}}{\varphi_{w, t}-1}}
$$

where $\varphi_{w, t}$ measures the time-varying price elasticity of demand for different types of labor. It acts as a wage markup shock in the labor market.

Staggered wages are introduced in the manner proposed by Erceg et al. (2000). Households are price setters in the labor market. In other words, wages are taken as a given by the intermediate-good firms. Following Calvo (1983), in each time period only a random fraction $1-\theta_{w}$ of households have the opportunity to reset their wages. This fraction is independent across households and time. In addition, the model assumes that households who cannot reset their wages simply index to lagged inflation as in Christiano et al. (2005). Therefore, the wage index $W_{j, t}$ is given by:

$$
W_{j, t}^{1-\varphi_{w, t}}=\theta_{w}\left[\left(\frac{P_{t-1}}{P_{t-2}}\right)^{\gamma_{w}} W_{j, t-1}\right]^{1-\varphi_{w, t}}+\left(1-\theta_{w}\right)\left(W_{j, t}^{*}\right)^{1-\varphi_{w, t}}, \quad 0 \leq \theta_{w} \leq 1, \quad 0 \leq \gamma_{w} \leq 1
$$

where $\gamma_{w}$ is the degree of wage indexation, and $W_{j, t}^{*}$ represents the nominal wage level chosen by those households who can reset their wages at time period t.

The intermediate-good firms face the same restriction in setting their prices. In each time period, the probability of being able to reset prices is $1-\theta_{p}$, and firms who cannot reset their prices also index to lagged inflation. The price index $P_{j, t}$ is given by:

$$
P_{j, t}^{1-\varphi_{p, t}}=\theta_{p}\left[\left(\frac{P_{t-1}}{P_{t-2}}\right)^{\gamma_{p}} P_{j, t-1}\right]^{1-\varphi_{p, t}}+\left(1-\theta_{p}\right)\left(P_{j, t}^{*}\right)^{1-\varphi_{p, t}}, \quad 0 \leq \theta_{p} \leq 1, \quad 0 \leq \gamma_{p} \leq 1
$$

The linearized first-order conditions are given by: 


$$
\begin{aligned}
m c_{t}= & \alpha r_{k, t}+(1-\alpha) w_{t}-\xi_{z, t} \\
w_{t}= & \frac{1}{1+\beta}\left\{w_{t-1}+\beta E_{t} w_{t+1}+\gamma_{w} \pi_{t-1}-\left(1+\beta \gamma_{w}\right) \pi_{t}+\beta E_{t} \pi_{t+1}\right. \\
& \left.-\frac{\left(1-\beta \theta_{w}\right)\left(1-\theta_{w}\right)}{\left(1+\varphi_{w} \eta_{n}\right) \theta_{w}}\left[w_{t}-\eta_{n} n_{t}-\frac{\eta_{c}}{1-h}\left(c_{t}-h c_{t-1}\right)\right]\right\}+\epsilon_{w, t} \\
\pi_{t}= & \frac{1}{1+\beta \gamma_{p}}\left[\gamma_{p} \pi_{t-1}+\beta E_{t} \pi_{t+1}+\frac{\left(1-\beta \theta_{p}\right)\left(1-\theta_{p}\right)}{\theta_{p}} m c_{t}\right]+\epsilon_{p, t}
\end{aligned}
$$

Equation (14) implies that the real marginal cost is a function of the real rental rate of capital and the real wage, since capital and labor are used in producing the intermediate goods. The real wage equation (15) states that, under staggered wage contracts, the representative household takes into account not only past and expected future real wages, but also past, current, and expected future inflation rates. The representative household sets her real wage higher than the marginal rate of substitution, since she knows there is a possibility that she may not be able to reset her wage in the future. It is worth noting that the real wage equation contains both backward-looking and forward-looking components, which induce inertia in inflation through marginal $\operatorname{costs}^{5}$. The New Keynesian Phillips curve (16) implies that inflation depends on past and expected future inflation. It also shows that the price indexation parameter $\gamma_{p}$ governs persistence in the response of inflation to a given shock. If $\gamma_{p}=0$, equation $(16)$ becomes a purely forward-looking Phillips curve. Finally, it shows that inflation is a function of the current marginal cost, and that both $\gamma_{p}$ and $\theta p$ govern the contribution of marginal cost to the persistent response of inflation. Here, we follow Gali and Gertler (1999)'s argument that, as the theory suggests, real marginal cost is a significant and quantitatively important determinant of inflation, instead of an ad hoc output gap.

\subsection{Monetary authority}

The monetary authority adjusts its instrument, the nominal short-term interest rate, in response to the deviations of output and inflation from their steady-state values:

$$
i_{t}=\kappa_{i} i_{t-1}+\left(1-\kappa_{i}\right)\left(\kappa_{\pi} \pi_{t}+\kappa_{y} y_{t}\right)+\xi_{i, t}
$$

\footnotetext{
(16).

${ }^{5}$ As shown in (14), marginal cost is an increasing function of real wages, and marginal cost appears in the inflation equation
} 
The monetary policy shock $\xi_{i, t}$ is assumed to follow an $\mathrm{AR}(1)$ process:

$$
\xi_{i, t}=\rho_{i} \xi_{i, t-1}+\epsilon_{i, t}, \quad 0 \leq \rho_{i}<1, \quad \epsilon_{i, t} \sim \text { i.i.d. }\left(0, \sigma_{i}^{2}\right)
$$

\subsection{Introducing the cost-channel of monetary transmission}

Following Rabanal (2007), we introduce the cost-channel of monetary transmission by assuming that a fraction of firms have to borrow funds to pay their wage bill before they receive revenues from sales. As a result, the policy rate affects the marginal cost of hiring an extra unit of labor, and hence the real marginal cost of production. If the cost-channel of monetary transmission is present, the linearized real marginal cost 14 becomes:

$$
m c_{t}=\alpha r_{k, t}+(1-\alpha)\left(w_{t}+\gamma i_{t}\right)-\xi_{z, t}
$$

This approach of introducing the cost-channel of monetary transmission was originally proposed by Christiano and Eichenbaum (1992). By assuming that workers must be paid in advance of production and firms have to borrow money from a financial intermediary to pay their wage bill at the beginning of the period $^{6}$, Christiano and Eichenbaum (1992) introduce an additional component into the cost of labor. That is, the marginal cost of hiring an extra unit of labor becomes the product of the real wage and the nominal short-term interest rate. The policy rate affects the real marginal cost directly, whereas real marginal cost is a significant and quantitatively important determinant of inflation, as discussed in Section 3.3. Therefore, an increase in the policy rate increases inflation through the cost-channel of monetary transmission.

\section{Simulation and results}

In this Section, we investigate the effects of monetary policy for the South African economy. The baseline model, a New Keynesian model with the cost-channel of monetary transmission, is calibrated to the South African economy ${ }^{7}$. We conduct a number of simulation exercises that are based on the baseline model and its variants to investigate when the SARB should apply contractionary policy to forestall inflation.

\footnotetext{
${ }^{6}$ Which is the case for $\gamma=1$ in Rabanal (2007).

${ }^{7}$ For the details of calibration, see Appendix.
} 


\subsection{The cost-channel effect of monetary policy}

We first study the dynamic responses of output, inflation, and the policy rate to a contractionary policy shock in the baseline model with and without the cost-channel of monetary transmission. By setting $\gamma=0$, the assumption that a fraction of firms need to borrow money to pay their wage bill before selling their product no longer holds. For the model including the cost channel of monetary transmission (the baseline model), we set $\gamma=0.7$, which implies that more than half of the firms have to borrow money to pay their wage bill.

Figure 3 shows that without the cost-channel of monetary transmission, the impulse response function of inflation to a contractionary policy shock is inconsistent with the VAR-based empirical evidence presented in Section 2, Following the monetary contraction, inflation decreases immediately and starts increasing three quarters after the shock occurs, and it eventually reverts to its steady state after ten quarters. This indicates that a standard New Keynesian model is not capable of mimicking the price puzzle produced by an estimated VAR. In the absence of labor market frictions, a contractionary policy shock causes a substantial decline in labor demand and investment. As a result, monetary contraction leads to a substantial decline in real wages and the rental rate of capital $r_{k, t}$, and hence, the real marginal cost of production. Therefore, inflation always declines in response to a contractionary policy shock.

Ravenna and Walsh (2006) show that in a standard New Keynesian model with the cost-channel of monetary transmission, firms' real marginal cost depends directly on the policy rate. As a result, the policy rate acts as a cost-push shock, and inflation always increases in response to an increase in the policy rate through the cost-channel of monetary transmission. As shown in Figure 3, the baseline model, a standard New Keynesian model with the cost-channel of monetary transmission, successfully mimics the price puzzle observed in an estimated VAR. It suggests that, in the presence of the cost-channel of monetary transmission, the SARB would not succeed in fighting inflation simply by mechanically following the conventional view that a contractionary policy should, in principle, decrease future inflation.

Figure 3 also shows the effects of the shock on output and the policy rate. The responses of output and policy rate to monetary contraction are consistent with the VAR-based empirical evidence. A contractionary policy shock leads to a substantial persistent decrease in output and an increase in the policy rate. Moreover, the response of output is stronger in the presence of the cost-channel than that without it, indicating that 
Figure 3: Model with cost-channel (solid line) vs model without cost-channel (dashed line)
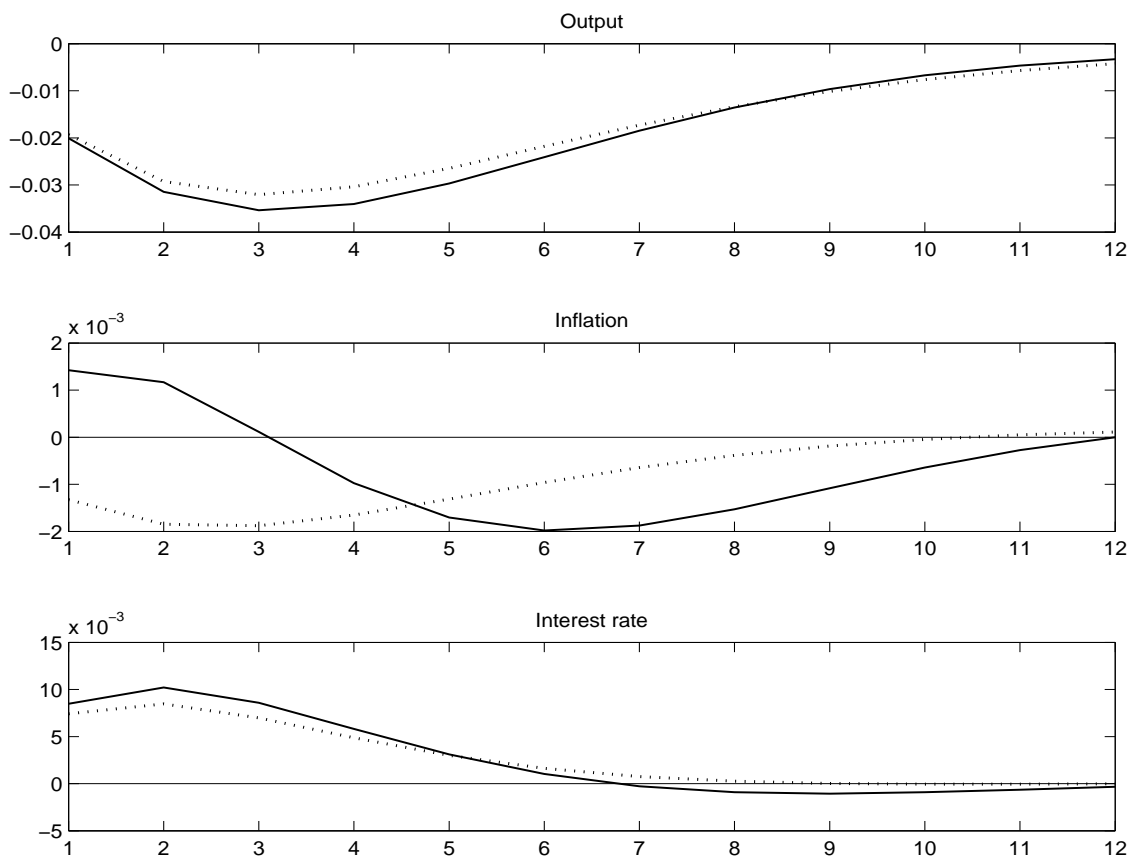

the cost-channel of monetary transmission amplifies the impacts of monetary policy shock on real variables in the short run.

\subsection{Cost-channel (supply-side) effect vs demand-side effect}

As discussed in Section 4.1, monetary policy shocks have both supply-side and demand-side effects, at least in the short run. It appears that, in the absence of the cost-channel, a contractionary policy shock always leads to a persistent decline in inflation due to the usual demand-side effect: an increase in the policy rate discourages investment and decreases labor demand, and hence, results in a decline in real wage and return on capital. However, Barth and Ramey (2001) argue that the cost-channel effect of a monetary policy shock may be greater than the demand-side effect. Therefore, it is crucial for SARB to understand whether, or to what extent, an increase in expected future inflation is due to supply shocks, before applying contractionary policy to forestall inflation.

In this section, we conduct the second simulation exercise to investigate to what extent the cost-channel effect dominates the demand-side effect of a monetary policy shock. In the baseline model, parameter $\gamma$ controls the fraction of firms that have to borrow money to pay their wage bill before they sell their 
products. The policy rate affects the marginal cost of hiring an extra unit of labor, and hence, the real marginal cost of production, whereas $\gamma$ determines the magnitude of the impact of the policy rate on real marginal cost. Therefore, it is possible to investigate the extent of the cost-channel effect of a monetary policy shock by controlling the value of parameter $\gamma$.

Figure 4 shows the impulse response functions of inflation to monetary contraction, with different values for parameter $\gamma$. In the case of $\gamma=1$, it simply assumes that all firms have to borrow money to pay their wages bill before they sell their products, meaning the strongest cost-channel effect of monetary policy exists in the model. As the value of $\gamma$ declines, the cost-channel effect becomes weaker and weaker. Based on our simulation exercises, we find that the demand-side effect of monetary policy shock starts dominating if $\gamma<0.36$. As a result, a contractionary policy shock leads to a persistent decline in inflation, and the price puzzle disappears. Therefore, the SARB can only succeed in fighting inflation by applying contractionary policy if an increase in expected future inflation is mainly due to demand shocks.

If the cost-channel effect dominates, an increase in the policy rate increases real marginal cost immediately, and hence, inflation ensues. Inflation only starts to decline two quarters after the shock occurs. If the SARB keeps hiking the policy rate to fight inflation, as it did over the period 2007Q1-2008Q2, instead of a decline in future inflation, what the SARB would face is a persistent increase in future inflation. This is because a cost-push shock arises endogenously with the presence of the cost-channel of monetary transmission in a standard New Keynesian model (Ravenna and Walsh, 2006). As a result, every increase in the policy rate exaggerates the cost-channel effect of the monetary policy shock and continuously increases real marginal cost, and hence, inflation ensues. Therefore, it is not surprising that inflation followed the same path as the policy rate in 2007 and 2008, as is shown in Figure 2 .

Figure $[5$ shows that regardless of whether the cost-channel effect dominates the demand-side effect of a monetary policy shock, monetary contraction always leads to a persistent decline in output. However, as the cost-channel effect increases (increase in $\gamma$ ), monetary contraction leads to a greater decline in output. That is, in the presence of the cost-channel, a contractionary policy shock has an effect primarily through production costs, resulting in a persistent decline in output and an increase in inflation. The cost of fighting inflation increases as the cost-channel effect increases. Once the cost-channel effect starts dominating the demand-side effect of the monetary policy shock $(\gamma>0.36)$, the SARB would face an increase in inflation and a greater loss in output when implementing a monetary contraction to forestall inflation. 
Figure 4: Policy effect on inflation: cost-channel (supply-side) effect vs demand-side effect

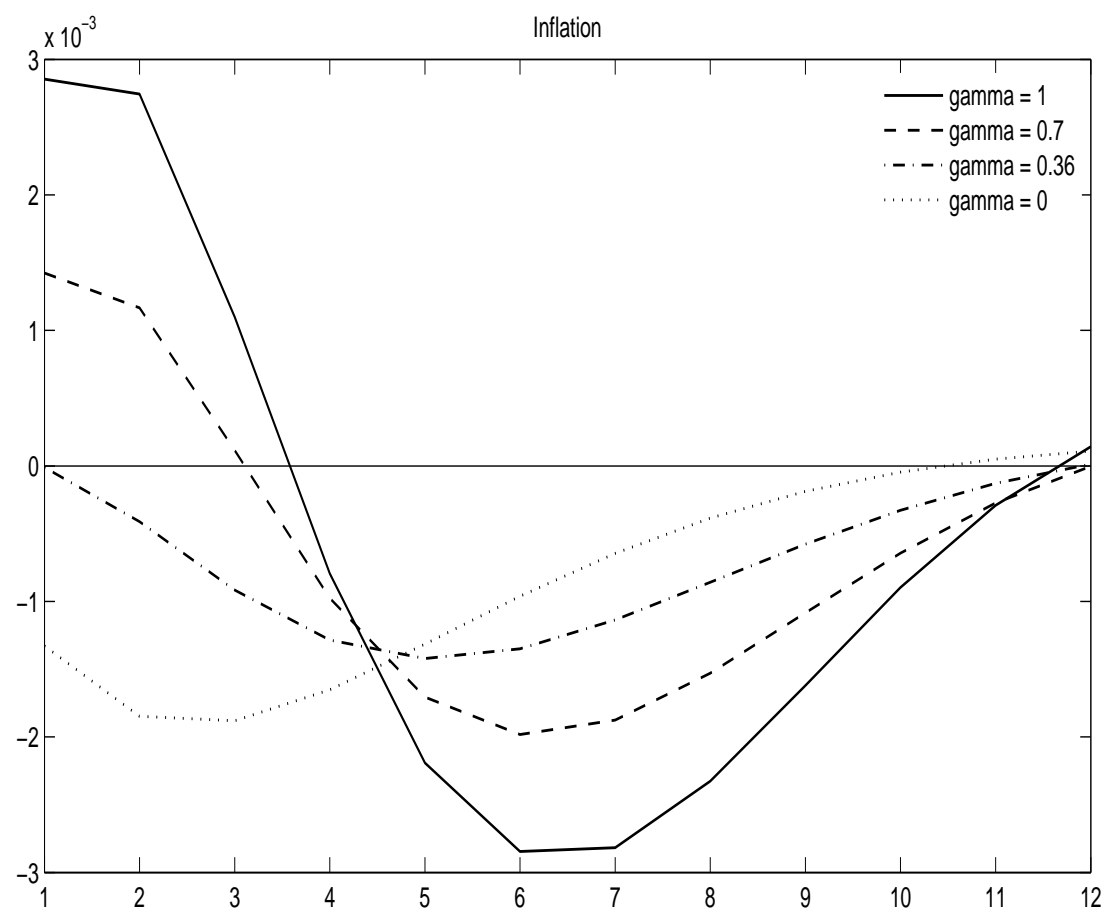

Figure 5: Policy effect on output: cost-channel (supply-side) effect vs demand-side effect

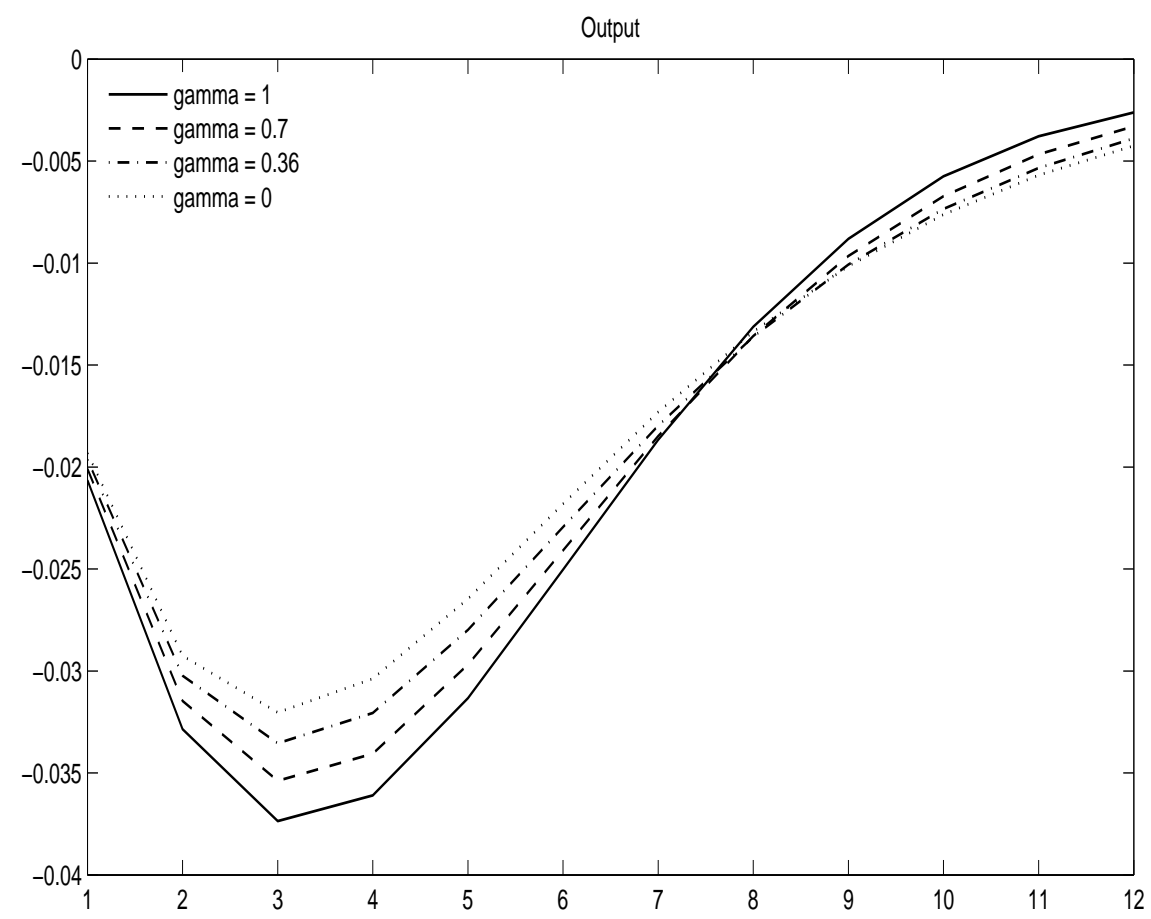




\section{Conclusions}

In this paper, we study the effects of monetary policy on the South African economy, specifically on inflation and output. The conventional view suggests that a contractionary monetary policy shock should decrease future inflation, whereas the empirical evidence shows a significantly positive response of inflation to the shock. Using a standard New Keynesian model with the cost-channel of monetary transmission, we show that the puzzle emerges only if the cost-channel effect dominates the demand-side effect of a monetary policy shock.

Whether or not the SARB should apply contractionary policy to forestall inflation depends critically on the nature of the disturbance. In principle, if an increase in expected future inflation is predicted to be mainly due to supply shocks, the SARB should not apply contractionary policy to forestall inflation. Otherwise, the bank would face persistent increases in inflation and a greater loss in output. What the South African economy experienced in 2007 and 2008 could be a good lesson. 


\section{References}

Amato, J. D., Thomas, L., 2004. Implications of habit formation for optimal monetary policy. Journal of Monetary Economics 51 (2), 303-325.

Barth, M., Ramey, V., 2001. The cost channel of monetary transmission. NBER Macroeconomics Annual $16,199-240$.

Bernanke, B., Gertler, M., 1995. Inside the black box: The credit channel of monetary policy transmission. Journal of Economic Perspectives 9 (4), 27-48.

Bouakez, H., Cardia, E., Ruge-Murcia, F. J., 2005. Habit formation and persistence of monetary policy. Journal of Monetary Economics 52 (6), 1073-1088.

Calvo, G., 1983. Staggered prices in a utility-maximizing framework. Journal of Monetary Economy 12 (3), $383-398$.

Christiano, L., Eichenbaum, M., 1992. Liquidity effects and the monetary transmission mechanism. American Economic Review 82 (2), 346-353.

Christiano, L., Eichenbaum, M., Evans, C., 1997. Sticky price and limited participation models of money: A comparison. European Economic Review 41 (6), 1201-1249.

Christiano, L. J., Eichenbaum, M., Evans, C. L., 2005. Nominal rigidities and the dynamic effects of a shock to monetary policy. Journal of Political Economy 113 (1), 1-45.

Clarida, R., Gali, J., Gertler, M., 1999. The science of monetary policy: A new keynesian perspective. Journal of Economic Literature 27 (December), 1661-1707.

Dixit, A., Stiglitz, J., 1977. Monopolistic competition and optimum product diversity. American Economic Review 67 (3), 297-308.

Eichenbaum, M., 1992. Comments on interpreting the macroeconomic time series facts: the effects of monetary policy by c. a. sims. European Economic Review 36 (5), 1001-1011.

Erceg, C. J., Henderson, D. W., Levin, A. T., 2000. Optimal monetary policy with staggered wage and price contracts. Journal of Monetary Economy 46 (2), 281-313. 
Farmer, R., 1984. A new theory of aggregate supply. American Economic Review 74 (5), 920-930.

Farmer, R., 1988. What is a liquidity crisis. Journal of Economic Theory 46 (1), 207-244.

Fuhrer, J. C., 2000. Habit formation in consumption and its implications for monetary-policy models. American Economic Review 90 (3), 367-390.

Gali, J., Gertler, M., 1999. Inflation dynamics: A structural econometric analysis. Journal of Monetary Economics $44(2), 195-222$.

Hoover, K., Perez, S., 1994. Post hoc ergo propter hoc once more: An evaluation of "does monetary policy matter?" in the spirit of james tobin. Journal of Monetary Economics 34 (1), 89-99.

Ortiz, A., Sturzenegger, F., 2007. Estimating sarb's policy reaction rule. South African Journal of Economics $75(4), 659-680$.

Rabanal, P., 2007. Does inflation increase after a monetary policy tightening? answers based on an estimated dsge model. Journal of Economic Dynamic \& Control 31, 906-937.

Ravenna, F., Walsh, C. E., 2006. Optimal monetary policy with the cost channel. Journal of Monetary Economics 53 (2), 199-216.

Sims, C., 1992. Interpreting the macroeconomic time series facts: The effects of monetary policy. European Economic Review 36 (5), 975-1000.

Smets, F., Wouters, R., 2007. Shocks and frictions in us business cycles: A bayesian approach. American Economic Review 97 (3), 586-606. 


\section{Appendix: Calibration}

The baseline model is calibrated to the South African economy. The parameter values of the model are assigned according to the measured data during the sample period of 1970 to $2010^{8}$. Data are taken from the SARB Quarterly Bulletin.

The annual aggregate capital depreciation rate $\delta$ is obtained from the annual averaged values of $\frac{I}{Y}$ and $\frac{K}{Y}$. This yields an annual depreciation rate of 0.076 , or a quarterly rate of 0.019 . The standard real business cycle literature suggests that the capital and labor shares of output have been approximately constant. The capital output share $\alpha$ is equal to 0.26 , whereas the labor output share $1-\alpha$ is 0.74 . The steady state capital to output ratio $\frac{K}{Y}$ is equal to 1.7 . The discount factor $\beta$ is set at 0.99 as in the literature. The coefficient of relative risk aversion $\eta_{c}$ is set at one, whereas the inverse of the elasticity of work effort with respect to real wage $\eta_{n}$ is set at 1.5 . The habit formation parameter $h$ is set at 0.7 , which is consistent with the literature (Rabanal, 2007). In the baseline model, we set $\gamma$ as equal to 0.7 , meaning more than half of firms (70\%) need to borrow money to pay their wage bill before they sell their products.

The Calvo parameters and fraction coefficients of wage and price indexation are set as the following. The Calvo sticky wage parameter $\theta_{w}$ is assumed to be 0.75 , which implies that wages are fixed on average for four quarters or a year. Prices are fixed on average for two quarters, i.e. $\theta_{p}=0.5$. The degree of wage indexation is set at 0.7 , whereas the degree of price indexation is set at 0.5 .

The parameters of the monetary policy rule, $\kappa_{i}, \kappa_{\pi}$, and $\kappa_{y}$, are set at $0.73,1.11$, and 0.27 respectively. These values are taken from Ortiz and Sturzenegger (2007) ${ }^{9}$. As suggested by Clarida et al. (1999), monetary authorities should adjust the policy rate sufficiently (more than one-for-one with expected future inflation) to offset the disturbance in expected future inflation. That is, $\kappa_{\pi}$ should be greater than one. Finally, the persistence parameter of monetary policy shock is set at 0.75 .

\footnotetext{
${ }^{8}$ See Table 1

9Ortiz and Sturzenegger (2007) use a DSGE model to estimate SARB's policy reaction rule, where SARB's policy rule is a similar Taylor type of rule as the one in the baseline model.
} 
Table 1: Calibration

\begin{tabular}{lll}
\hline \hline Parameter & Value & Comments \\
\hline$\theta_{p}$ & 0.5 & Calvo sticky price parameter \\
\hline$\theta_{w}$ & 0.75 & Calvo sticky wage parameter \\
\hline$\gamma_{p}$ & 0.5 & Degree of price index \\
\hline$\gamma_{w}$ & 0.7 & Degree of wage index \\
\hline$\frac{K}{Y}$ & 1.7 & Steady state ratio of capita to output \\
\hline$\alpha$ & 0.26 & Capital share of output \\
\hline$\beta$ & 0.99 & Discount rate \\
\hline$h$ & 0.7 & Habit formation parameter \\
\hline$\eta_{c}$ & 1 & Coefficient of relative risk aversion of household \\
\hline$\eta_{n}$ & 1.5 & The inverse of the elasticity of work effort with respect to real wage \\
\hline$\delta$ & 0.019 & Capital depreciation rate \\
\hline$\gamma$ & 0.7 & Fraction of firms that need to borrow money to pay their wage bill \\
\hline$\rho_{i}$ & 0.75 & AR(1) parameter of monetary policy shock \\
\hline$\kappa_{i}$ & 0.73 & Parameter of lagged policy rate in Taylor rule \\
\hline$\kappa_{\pi}$ & 1.11 & Parameter of inflation in Taylor rule \\
\hline$\kappa_{y}$ & 0.27 & Parameter of output in Taylor rule \\
\hline \hline
\end{tabular}

